\title{
Poorly Differentiated Salivary Gland Squamous Cell Carcinoma
}

National Cancer Institute

\section{Source}

National Cancer Institute. Poorly Differentiated Salivary Gland Squamous Cell Carcinoma. NCl Thesaurus. Code C8022.

A poorly differentiated squamous cell carcinoma arising from the salivary gland. 